\title{
p73: A Multifunctional Protein in Neurobiology
}

\author{
Richard Killick • Maria Niklison-Chirou • Richard Tomasini • Daniele Bano • \\ Alessandro Rufini • Francesca Grespi • Tania Velletri • Paola Tucci • Berna S. Sayan • \\ Franco Conforti • Ewen Gallagher • Pierluigi Nicotera • Tak W. Mak • Gerry Melino • \\ Richard A Knight • Massimiliano Agostini
}

Received: 4 February 2011 / Accepted: 22 February 2011 /Published online: 8 March 2011

(C) The Author(s) 2011. This article is published with open access at Springerlink.com

\begin{abstract}
p73, a transcription factor of the p53 family, plays a key role in many biological processes including neuronal development. Indeed, mice deficient for both TAp73 and $\Delta \mathrm{Np} 73$ isoforms display neuronal pathologies, including hydrocephalus and hippocampal dysgenesis, with defects in the CA1-CA3 pyramidal cell layers and the dentate gyrus. TAp73 expression increases in parallel with neuronal differentiation and its ectopic expression induces neurite outgrowth and expression of neuronal markers in neuroblastoma cell lines and neural stem cells, suggesting that it has a pro-differentiation role. In contrast, $\Delta \mathrm{Np} 73$ shows a survival function in mature cortical neurons as selective $\Delta \mathrm{Np} 73$ null mice have reduced cortical thickness. Recent evidence has also suggested that $\mathrm{p} 73$ isoforms are
\end{abstract}

R. Killick

King's College London, Institute of Psychiatry,

Old Age Psychiatry and Dementia,

London SE5 8AF, UK

M. Niklison-Chirou • A. Rufini $\cdot$ F. Grespi $\cdot$ T. Velletri $\cdot$ P. Tucci $~$ B. S. Sayan $\cdot$ F. Conforti $\cdot$ G. Melino $\cdot$ R. A. Knight $(\triangle) \cdot$ M. Agostini $(\triangle)$

Medical Research Council, Toxicology Unit, Leicester University, Leicester LE1 9HN, UK

e-mail: r.knight@ich.ucl.ac.uk

M. Agostini

e-mail: ma285@1eicester.ac.uk

R. Tomasini

Institut National de la Sante et de la Recherche Medicale, Unite 624, Stress Cellulaire, Parc Scientifique et Technologique de Luminy,

13288 Marseille Cedex 9, France

deregulated in neurodegenerative pathologies such as Alzheimer's disease, with abnormal tau phosphorylation. Thus, in addition to its increasingly accepted contribution to tumorigenesis, the p73 subfamily also plays a role in neuronal development and neurodegeneration.

Keyword $\mathrm{p} 73 \cdot$ Neuronal differentiation $\cdot$ Neural stem cells (NSC) $\cdot$ Neurodegeneration · Alzheimer's Disease

\section{The Molecular Nature of p73}

p73 is a member of the p53 family [1], although p73 (and p63) are more closely related to the ancestral form of the

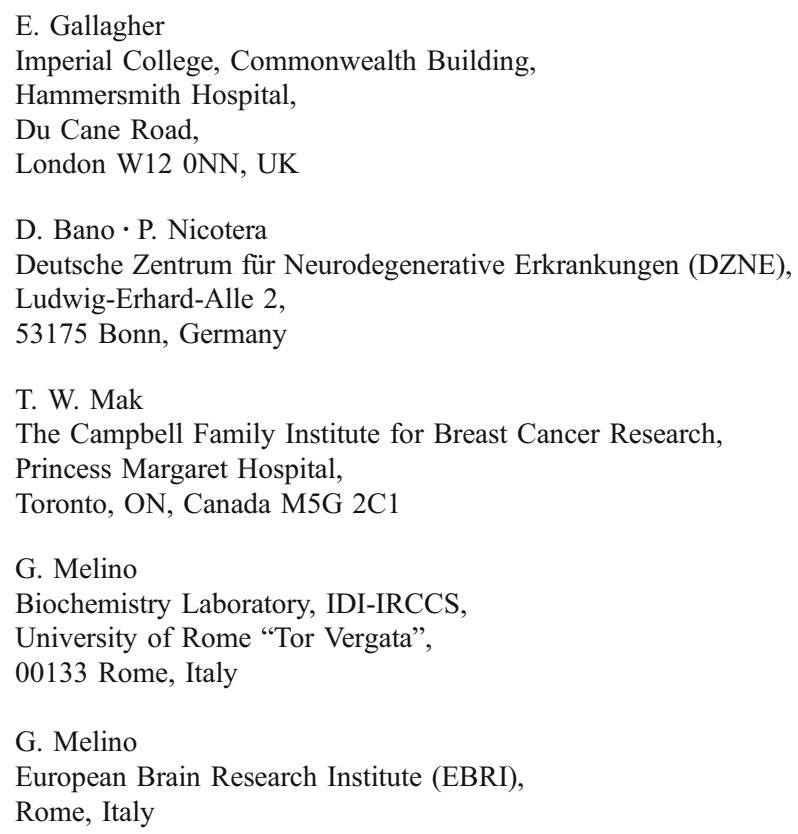


protein than $\mathrm{p} 53$. These three mammalian genes encode transcription factors that play key roles as regulators of proliferation, differentiation, cell death, stem cell renewal, and cell fate commitment [2-4]. All p53 family genes contain the same modular domain structure, including an amino-terminal transactivation domain (TA), a DNAbinding domain and a carboxy-terminal oligomerization domain. The $\mathrm{p} 73$ gene contains 15 exons and transcription can be initiated from two N-terminal promoters (Fig. 1). Transcription from the most upstream ATG (promoter 1) generates the transactivating (TA) isoforms, while the second promoter, situated within intron 3 , yields aminoterminal truncated proteins ( $\Delta \mathrm{N}$ isoforms). In general, $\mathrm{TA}$ and $\Delta \mathrm{N}$ isoforms display distinct biological activities. The TA isoforms induce cell cycle arrest and apoptosis, and are therefore candidate tumour suppressors $[5,6]$ while the truncated $\Delta \mathrm{N}$ isoforms are (generally) pro-survival and favour oncogenic transformation [7]. In addition, both TAp73 and $\Delta \mathrm{Np} 73$ transcripts undergo alternative $\mathrm{C}$-terminal splicing, generating, in theory, up to seven different variants of each in normal cells, although not all these have been detected at the protein level [8-10]. This complexity has led to significant difficulties in understanding the biology of $\mathrm{p} 73$.

It is, however, now generally accepted that $\Delta \mathrm{N}$ isoforms largely act as dominant negative inhibitors of the activity of TA isoforms, both by competing for consensus elements in promoter DNA and by dimerisation [7, 11]. However, this generalisation must be qualified since the longest $\Delta \mathrm{Np} 73 \alpha$ isoform contains a second $\mathrm{C}$-terminal TA domain and can transactivate a set of genes distinct from that recognised by TAp73. Moreover, the $\alpha$ isoforms of both TA and $\Delta \mathrm{Np} 73$ contain a C-terminal transactivation inhibitory domain, which can compromise the transcriptional activity mediated by the N-terminal TA domain as a result of intramolecular interactions. Thus, to regard the output of $\mathrm{p} 73$ expression as the resultant of the ratio between TA and $\Delta \mathrm{N}$ isoform expression may be an oversimplification.

\section{The Biology of p73: Lessons from Transgenic Mice}

The human Trp73 gene was identified in 1997 when it was localised within chromosome $1 \mathrm{p} 36$, a region frequently deleted in tumours such as neuroblastoma and other latestage human cancers [12, 13]. Monosomy $1 \mathrm{p} 36$ is also associated with developmental brain abnormalities [14]. Although genes other than $\mathrm{p} 73$ within the $1 \mathrm{p} 36$ region, such as CHD5, may also contribute to these phenotypes, these data suggest that p73 may have a role in neural development as well as in cancer.

This developmental role for $\mathrm{p} 73$ is substantiated by the phenotype of total p73 knockout mice. Unlike the tumoursusceptible p53 null mice, total p73 knockout mice do not develop tumours but show developmental defects in the central nervous system (Table 1) [15], including congenital hydrocephalus and hippocampal dysgenesis, with abnormalities in the CA1-CA3 pyramidal cell layers and the dentate gyrus. In keeping with these anatomical abnormalities, the total $\mathrm{p} 73^{-/-}$knockout mice also have defects in both embryonal and adult neurogenesis, suggesting that $\mathrm{p} 73$ isoforms may be survival factors for neural stem cells [16]. $\mathrm{p} 73^{-/}$mice also have a reduction in cortical thickness as a consequence of loss of mature cortical neurons [17].
Fig. 1 p73 gene structure. a Genomic organisation of $\mathrm{p} 73$ and representation of different splicing variants that give rise to the isoforms of $\mathrm{p} 73$. The P1 promoter generates the TA isoforms, while the $\mathrm{P} 2$ promoter produces the $\Delta \mathrm{N}$ isoforms. b Schematic representation of the domains encoded by the different isoforms of p73. On top, there are indicated the aminoacids included in each domain. $T A$ transactivation domain, $D B D$ DNA-binding domain, $O D$ oligomerization domain, SAM SAM domain, TID transactivation inhibitory domain
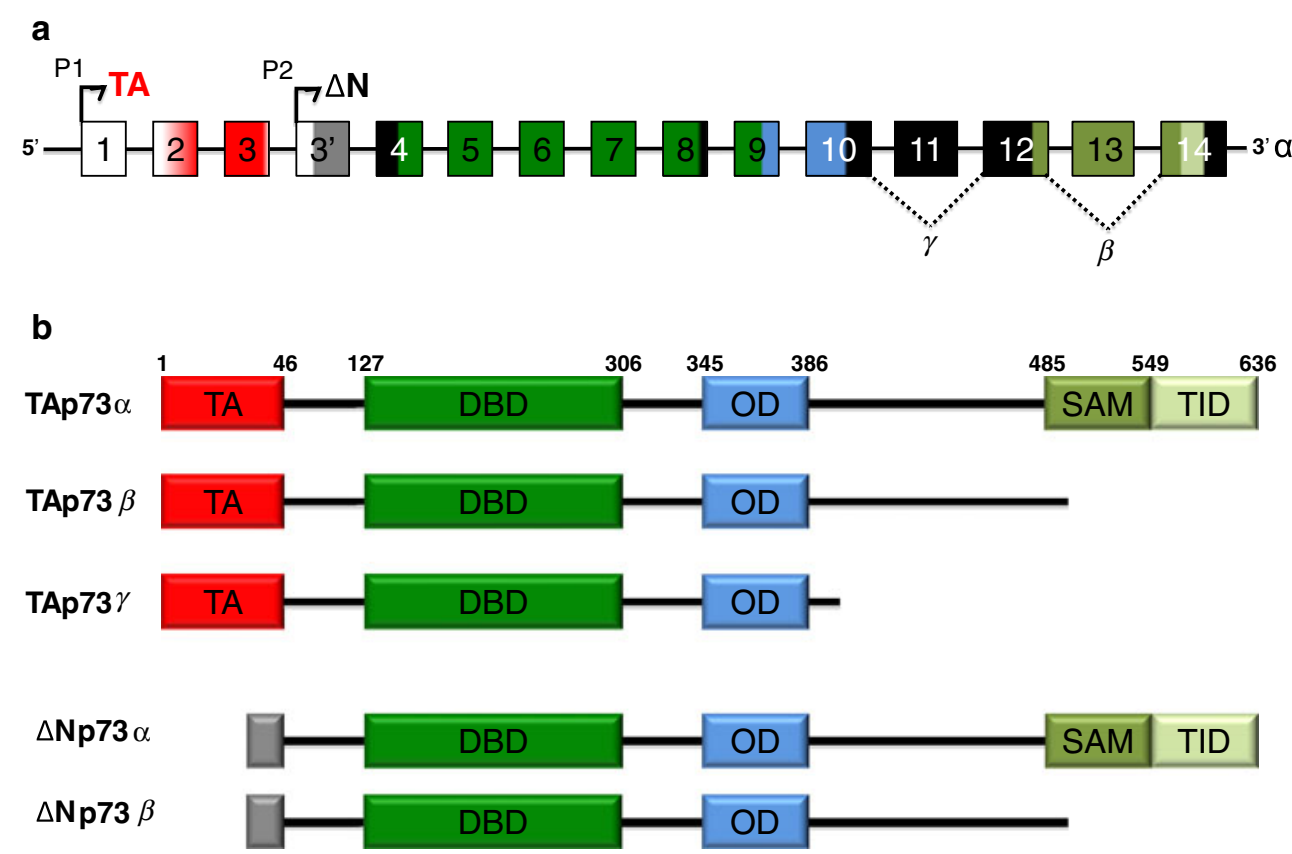
Table 1 Neuronal defects in p73 transgenic mice

\begin{tabular}{|c|c|c|c|c|c|c|}
\hline & \multicolumn{2}{|c|}{$\begin{array}{l}\text { p73 } \\
\text { (Yang et al. [15], Pozniak et al. [17]) }\end{array}$} & \multicolumn{2}{|c|}{$\begin{array}{l}\text { TAp } 73^{-/-} \\
\text {(Tomasini et al. [22]) }\end{array}$} & \multicolumn{2}{|c|}{$\begin{array}{l}\text { DNp73 } \\
\text { (Wilhelm et al. [19]) }\end{array}$} \\
\hline \multicolumn{7}{|l|}{ Anatomical defect } \\
\hline Cortex & \multicolumn{2}{|c|}{ Hypoplasia } & \multicolumn{2}{|l|}{ None } & \multicolumn{2}{|c|}{$\begin{array}{l}\text { Age-dependence hypocellularity } \\
\text { and cortex thinning }\end{array}$} \\
\hline Hippocampus & \multicolumn{2}{|c|}{ Dysgenesis } & \multicolumn{2}{|c|}{$\begin{array}{l}\text { Absence lower blade of } \\
\text { dentate gyrus }\end{array}$} & \multicolumn{2}{|c|}{ None } \\
\hline Ventricular & \multicolumn{2}{|c|}{ Third ventricle enlarged and hydrocephalus } & \multicolumn{2}{|c|}{ None } & \multicolumn{2}{|c|}{ Enlarged ventricle } \\
\hline Others & \multicolumn{4}{|c|}{$\begin{array}{l}\text { Loss of Cajal-Retzius neurons and Reelin defective. } \\
\text { Abnormalities of the pheromone sensory pathway }\end{array}$} & & \\
\hline \multirow[t]{2}{*}{ Behavioural test } & \multicolumn{2}{|c|}{ (Talos et al. [16], Wetzel et al. [19]) } & \multicolumn{2}{|c|}{ (Personal communication) } & \multicolumn{2}{|c|}{ (Personal communication) } \\
\hline & Young & Aged & Young & Aged & Young & Aged \\
\hline Burrowing & NT & NT & Reduced & Reduced & NT & Normal \\
\hline Clasping & Positive & Reduced $^{\mathrm{a}}$ & Positive & Positive & NT & Positive \\
\hline Open field & Reduced & Reduced $^{\mathrm{a}}$ & Reduced & Reduced & NT & Reduced \\
\hline Barnes Maze & Reduced & Reduced $^{\mathrm{a}}$ & NT & NT & NT & NT \\
\hline Hind grip & Loose & Reduced $^{\mathrm{a}}$ & NT & NT & NT & NT \\
\hline Light-dark box & Positive & NT & NT & NT & NT & NT \\
\hline
\end{tabular}

Young mice: 2-4 months old. Aged mice: $15-17$ months old

$N T$ not tested

${ }^{\mathrm{a}}$ The behavioural experiments were performed in $\mathrm{p} 73^{+/-}$mice

This neurological phenotype has been attributed primarily to the loss of $\Delta \mathrm{Np} 73$ isoforms, since these are expressed in post-mitotic neurons and act as survival factors [11]. Thus, NGF withdrawal or overexpression of p53 in sympathetic cervical ganglion cells leads to a reduction of endogenous $\Delta \mathrm{Np} 73$ levels and apoptosis which is prevented by overexpression of $\Delta \mathrm{Np} 73$ [18]. Recently, the generation of $\Delta \mathrm{Np} 73$ isoform-specific KO mice has confirmed the prosurvival role of $\Delta \mathrm{Np} 73$ in differentiated mature neurons [19]. Indeed, neuronal density in the motor cortex of $\Delta \mathrm{Np} 73^{-/-}$mice is significantly reduced after 10 months of age and progresses with evidence of neurodegeneration [20], although there were no striking hippocampal abnormalities. The same phenotype is also evident in a second $\Delta \mathrm{Np} 73^{-/}$ mouse model [21]. In particular, it has been observed that the number of vomeronasal neurons and Cajal-Rezius cells was profoundly reduced, and that the choroid plexuses were atrophic.

However, the severity of the neurological defects observed in the $\Delta \mathrm{Np} 73$-specific knockout is not as dramatic as that seen in the total $\mathrm{p} 73^{-/-}$mice, suggesting that TAp73 may also contribute to the development of the CNS. While cortical thickness in selective TAp73 null mice is normal, they show hippocampal dysgenesis with loss of the lower blade of the dentate gyrus similar to that seen in total $\mathrm{p} 73^{-/-}$mice at P14, before the complicating effect of ventricular enlargement further distorts the hippocampal architecture in the total knockout [22]. This anatomical phenotype is reflected in the reduction in neurogenesis in the subgranular zone of the dentate gyrus (Fig. 2), suggesting that TAp73 may be required for neural stem cell proliferation [23]. Indeed, TAp73 has been shown to regulate the negative bHLH Hey2 which is known to sustain maintenance of neural precursors. Thus, the isoform-selective knockout studies suggest that TAp73 and $\Delta \mathrm{Np} 73$ contribute to CNS development in ways that are only partially overlapping.

\section{Differentiation or Stemness?}

Both embryonic and adult neural stem cells (NSC) are primary precursors that have the ability to differentiate into different cell types (neurons, astrocytes and oligodendrocytes) while retaining the capacity to produce identical NSC progeny (self-renewal) [24], and p53 and $\Delta \mathrm{Np} 63$ have already been implicated in NSC biology $[25,26]$. Recently, four independent groups [16, 23, 27, 28] have demonstrated that $\mathrm{p} 73$ is also a positive regulator of embryonic and adult NSC and some of this in vivo evidence has been discussed above.

NSC can be cultured in vitro as neurospheres and subsequently differentiated into mature neurons. Neurospheres derived from $\mathrm{p} 73^{-/-}$mice are smaller, with a reduced number of cells in $\mathrm{S}$ phase and an increase in the 
Fig. 2 Reduction of the putative stem cell in the dentate gyrus from $\mathrm{p} 73^{-/-}$mice. The dentate gyrus from day 7 after birth (P7) of normal $\left(\mathrm{p} 73^{+/+}\right)$ and knockout $\left(\mathrm{p} 73^{-1-}\right)$ mice was stained with antibodies to glial fibrillary acidic protein (GFAP) and nestin. Arrows indicate double-positive cells. Knockout mice show nearly half of GFAP/Nestin cells, indicating a very reduced stemness potential in these mice. $G L$ granular cell layer, $M L$ molecular cell layer, Hil hilus. Scale bars $50 \mu \mathrm{m}$

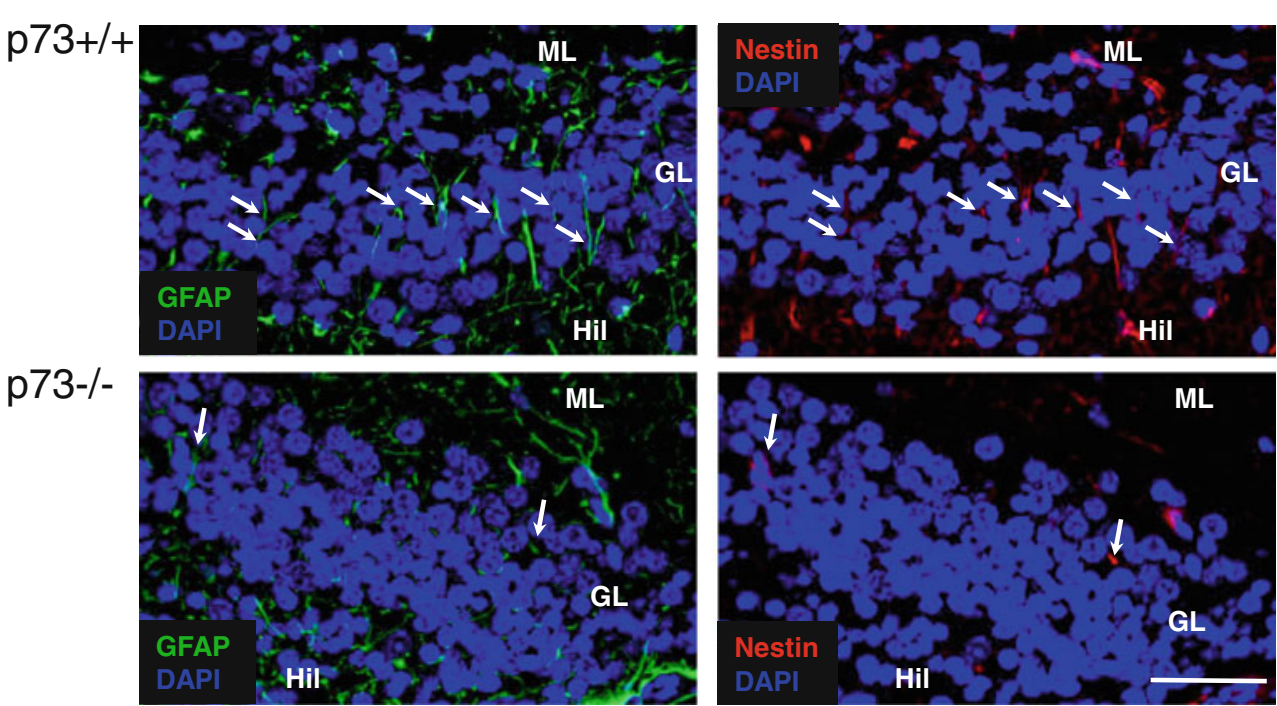

senescent population [16]. At the molecular level, it has been shown that NSC from $\mathrm{p} 73^{-/-}$mice have transcriptional dysregulation of Sox-2, Sox-3, Nanog, Notch-I, Notch-2, Hes-5, Jag2 and Deltex, which are all components of signalling pathways involved in the regulation of proliferation and/or self-renewal [29], although further studies are required to address how $\mathrm{p} 73$ physiologically regulates these factors. TAp73 is the predominant isoform expressed in embryonic NSC, and endogenous expression of TAp73 increases during differentiation of NSC [27]. Further studies have shown that smaller numbers of neurons can be derived from $\mathrm{p} 73^{-/}$NSC which do not fully differentiate, with defects in arborization of the dendritic tree and in physical connectivity. This is reflected in the anatomy of hippocampal neurons in the dentate gyrus of $\mathrm{p} 73^{-/-}$mice in vivo, which show a reduced number of branches when compared to normal mice (Fig. 3).

p73 has also been implicated in oligodendrocyte as well as neuronal differentiation [30], and oligodendrocytic differentiation from $\mathrm{p} 73^{-/}$NSC is also impaired, with lower numbers and poorer quality than those derived from wild type NSC. However, dissociated $\mathrm{p} 73^{-/-}$NSC retain the ability to differentiate into neurons, astrocytes and oligodendrocytes, indicating that loss of p73 does not affect the multipotency of NSC.

Another, though perhaps less definitive model implicating p73 in neurogenesis is the terminal differentiation of neuroblastoma cells induced by retinoic acid (RA) and which is associated with an increased expression of TAp73. In addition, ectopic expression of TAp73 itself induces terminal neuronal differentiation. During RA treatment, TAp73 isoforms regulate the N-CAM promoter, while ectopic expression of TAp73 led to a down-regulation of $\mathrm{N}-\mathrm{MYC}$ and an increased expression of $\mathrm{pRB}$, mimicking the RA effect on these two genes [31], which are crucial for neuroblastoma survival $[32,33]$.
In conclusion, while recent work indicates a clear requirement for $\mathrm{p} 73$, and particularly TAp73 in the maintenance of stemness via a yet not fully identified mechanism both in vivo and in vitro [16, 23, 27, 28], other data suggest an involvement of p73 in neuronal [31] and oligodendrocyte [30] differentiation. These multiple biological activities in the nervous system may reflect the

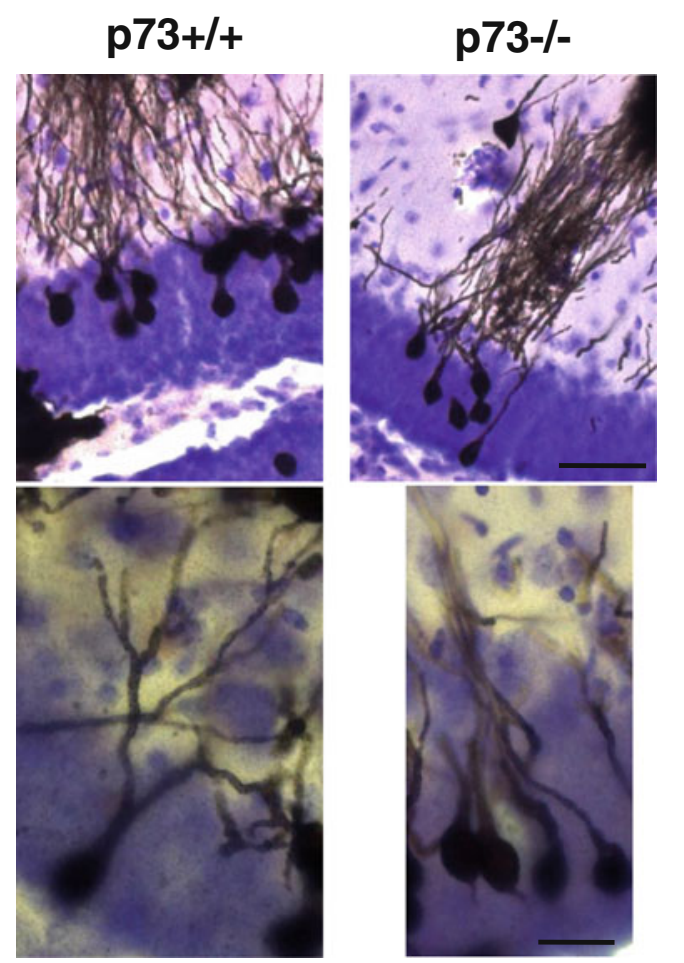

Fig. 3 Hippocampal neuron morphology is altered in the dentate gyrus of knockout $\left(\mathrm{p} 73^{-/}\right)$mice. Golgi staining of dentate gyrus from normal $\left(\mathrm{p} 73^{+/+}\right)$and $\mathrm{p} 73^{-/-}$mice (age $=18$ days after birth). Knockout mice show reduced branching and connectivity of neurons. A representative photomicrograph is shown. Scale bars $100 \mu \mathrm{m}$ (top panel) and $50 \mu \mathrm{m}$ (low panel) 
molecular complexity of the 14 protein isoforms of $\mathrm{p} 73$, their interactions with each other as well as their interplay with other p53/p63 family members, which are themselves expressed as multiple isoforms. Alternatively, since p73 appears to regulate between 1,000 and 2,000 genes, including 100-200 transcription factors, several apparently divergent pathways could be simultaneously activated.

\section{p73 and Neurodegeneration}

During the last 15 years, it has emerged that the p53 family has an important role in several neurodegenerative diseases. Of special interest to us, and on which we will focus, is their role in the most (and increasingly) prevalent form of neurodegeneration, Alzheimer's disease (AD).

$\mathrm{AD}$ exists as both familial and sporadic forms. The familial early onset (EOAD) form, accounting for only a small percentage of cases, is inherited via mutations in either the $\beta$-amyloid precursor protein (APP) or one of the two presenilins (PS), PS1 and PS2. In contrast, the greatest genetic risk for the sporadic, late onset (LOAD) form is the $\varepsilon 4$ allele of apolipoprotein E (APOE) [34]. Recently, genome-wide association studies have identified three additional risk genes, albeit with much weaker effects than APOE; ApoJ/CLU, PICALM and CR1 [35, 36]

Both sporadic and familial forms of the disease are characterised by two brain lesions: senile plaquesextracellular deposits of the $\beta$-amyloid (A $\beta$ ) peptide; and neurofibrillary tangles (NFTs) - intracellular aggregates of paired helical filaments (PHF) composed of hyperphosphorylated forms of the microtubule associated protein, tau [37]. The appearance of senile plaques precedes that of NFTs. $A \beta$ is derived by proteolytic processing from the APP, with the presenilins being a necessary component of the $\gamma$-secretase complex responsible for the final stage of this process [37]. The phosphorylation state of tau regulates its ability to bind microtubules; in its hyperphosphorylated state tau is unbound and eventually polymerises into paired helical filaments, which then aggregate into NFTs. It is emerging that it is not these insoluble aggregates of tau, but rather some soluble form that is the toxic species responsible for neuronal dysfunction and eventually neuronal death [38]. That mutations in APP give rise to increased $A \beta$ production (as do mutations in the presenilins, as subsequently observed), and as senile plaque appearance precedes that of NFTs, the amyloid cascade hypothesis was formulated [39]. This hypothesis, which has not yet been refuted, holds that increased levels of $A \beta$ lead to the hyperphosphorylation of tau which then leads to neuronal dysfunction and eventually neurodegeneration. Attempts to model this cascade of events in mice has for the most part failed, as even when mutant transgenic forms of both APP and PS1 are introduced, despite high levels of A $\beta$ production leading to extensive plaque formation, the aggregation of tau is not observed. It is only when APP, PS1 and human tau are concomitantly over expressed in triple transgenic mice that both plaques and tangles are observed.

The first indication that the p53 family may play a role in $\mathrm{AD}$ came in 1996 with the demonstration that intracellular $A \beta$ upregulates $p 53$ in the brains of transgenic mice overexpressing just the $A \beta$ fragment of APP [40]. That same year, the Kosik group examined neurons from a $\mathrm{p} 53^{-/-}$mouse, observing that $\mathrm{p} 53$ has a role in neuronal differentiation and in tau phosphorylation [41]. In 2001 use of pifithrin- $\alpha$, an inhibitor of p53dependent gene transcription was shown to protect neurons against $A \beta$-induced apoptosis [42]. The p53 protein was also found to be upregulated in the brain of AD sufferers [43], a finding which we later confirmed [44]. In 2004, Caricasole et al. [45] showed that $A \beta$ activates the expression of the p53 target gene encoding the soluble wnt antagonist, Dickkopf-1 (Dkk1) [46], and that knock-down of Dkk1 in primary neurons almost completely blocked $\mathrm{A} \beta$-induced tau phosphorylation, implicating the p53 family in the "amyloid cascade" pathway. In the same year, it was also reported [47] that the p73 protein exhibits an altered subcellular distribution in AD brain. In hippocampal pyramidal neurons of control subjects, p73 immunoreactivity was predominately cytoplasmic, while in $\mathrm{AD}$ samples increased levels of p73 were found in the nuclei of pyramidal neurons and in dystrophic neurites.

We employed a simple cell model to show that transcriptionally active forms of p53 are able to induce tau phosphorylation at specifc phosphoepitopes, particularly the AT8/Tau-1 (S199, S202 and S205) and PHF-1 (S396 and S404) sites [44]. We found that this also holds true for $\mathrm{p} 73$, with the TA forms increasing tau phosphorylation, while the $\Delta \mathrm{N}$ forms do not [48]. In this system, we also found that transcriptionally active forms of p63 activate tau phosphorylation, while $\Delta \mathrm{Np} 63$ forms do not (unpublished observations).

In 2008, the Miller/Kaplan group [49] reported that in brains of aged (16-18 months) heterozygous $\mathrm{p} 73^{+/-}$mice, there were substantial increases in tau phosphorylation levels together with filamentous aggregates of hyperphosphorylated tau with similarities to NFTs. When they crossed these haploinsufficent p73 mice with mice harbouring a double mutant form of APP (the TgCRND8 mouse), tau phosphorylation and tau filament formation occurred as early as 1.5 months. This finding is especially remarkable given that $\mathrm{A} \beta$-based mouse models of $\mathrm{AD}$ do 
not manifest overt tau pathology. It also lends yet further support to the amyloid cascade hypothesis, showing that A $\beta$ lies upstream of tau pathology and also that the cascade of events that $A \beta$ must set into motion, leading to the hyperphosphorylation of tau and subsequent neurodegeneration, involves the p53 family, and in particular p73.

The Miller/Kaplan group went on to show [49] that in primary cortical neurons generated from $\mathrm{p} 73 \mathrm{KO}$ mice the activity of c-jun N-terminal kinase (JNK) increased as the number of WT p73 alleles decreased, and that JNK inhibition decreased tau phosphorylation in these neurons. They propose that, since $\Delta \mathrm{Np} 73$ can bind and inhibit JNK, which the TA forms of $\mathrm{p} 73$ cannot, it is the loss of the $\Delta \mathrm{N}$ forms of p73 that brings about tau phosphorylation and neurodegeneration. The same group has previously demonstrated that $\Delta \mathrm{Np} 73$ plays a neuroprotective role in the CNS $[17,50]$ and also claim that $\Delta \mathrm{N}$ forms of $\mathrm{p} 73$ predominate, at least in the postnatal mouse brain. The loss of one copy of the entire $\mathrm{p} 73$ gene results in a reduction in $\Delta \mathrm{Np} 73$ isoforms leading to an increase in JNK activity.

In support of this claim, there is an extensive literature implicating JNK in AD pathology, e.g. [51-53]. Our group has shown that JNK directly targets tau [54] and also plays a role in the regulation of APP processing [55]. Inhibiting JNK has also been shown to protect against $\mathrm{A} \beta$ toxicity in an APP/PS1 brain slice model of AD [56].

There exists one other knock-out mouse with a phenotype that includes neurodegeneration with accompanying aggregates of hyperphosphorylated tau filaments [57]. The deleted gene is Prolylisomerase-1, which is associated with $\mathrm{A} \beta$ production and aggregation through its binding with phospho-Thr688 of APP, and tau phosphorylation through interaction with phospho-Thr231 of tau. Of interest, Pin1 also stabilises TAp73 via the c-Abl pathway [58].
$\mathrm{A} \beta$ has been shown to activate $\mathrm{c}-\mathrm{Abl}$ and increase p73 levels [59], while the Swedish mutant form of APP increases expression from both the TA and $\Delta \mathrm{N}$ promoters of the p73 gene, but results in an overall increase in the TA forms [60]. It appears then that p73 plays a key role in $\mathrm{AD}$ and, in particular, that the balance between the TA and $\Delta \mathrm{N}$ forms is crucial. However, from the above, and other observations such as the fact that p53 transcriptional activity is regulated by the presenilins and that many of the components of the $\gamma$-secretase complex are themselves regulated by $p 53$ [61], it would seem unlikely that p73 acts alone. Further investigations into p73 interactions with other p53 family members, in particular p53 itself, within nervous tissues will undoubtedly aid our understanding of its roles in both normal adult brain and in the pathogenic processes underlying Alzheimer's disease.

\section{Conclusion}

From these studies, it emerges that $\mathrm{p} 73$ is the $\mathrm{p} 53$ family member with a fundamental role in central nervous system development and maintenance, and even in its degeneration. Indeed, as shown in Fig. 4, the p73 gene plays a role throughout the neurogenesis process, from neural stem cells to mature postmitotic neurons. Although perhaps simplistic at this stage, these new findings suggest that TAp73 is the isoform essential for neuronal differentiation and maintenance of neural stem cells. In contrast, $\Delta \mathrm{Np} 73$ seems to play a major role in neuronal survival. However, the phenotype observed in isoform specific knock-out mice is milder than that in the full knock-out mice, indicating that, as in cancer, it is the interaction between $\mathrm{p} 73$ isoforms, which ultimately determines the phenotype.
Fig. 4 Role of p73 in neurogenesis. Functional neurons are generated from neural stem cells and then after maturation, integrated in neuronal circuits. TAp73 is essential for neuronal differentiation and maintenance of neural stem cells. $\Delta \mathrm{Np} 73$ plays a major role both as a survival mechanism as well as yet unknown pathways. Question marks indicate that molecular mechanism has not been fully investigated yet

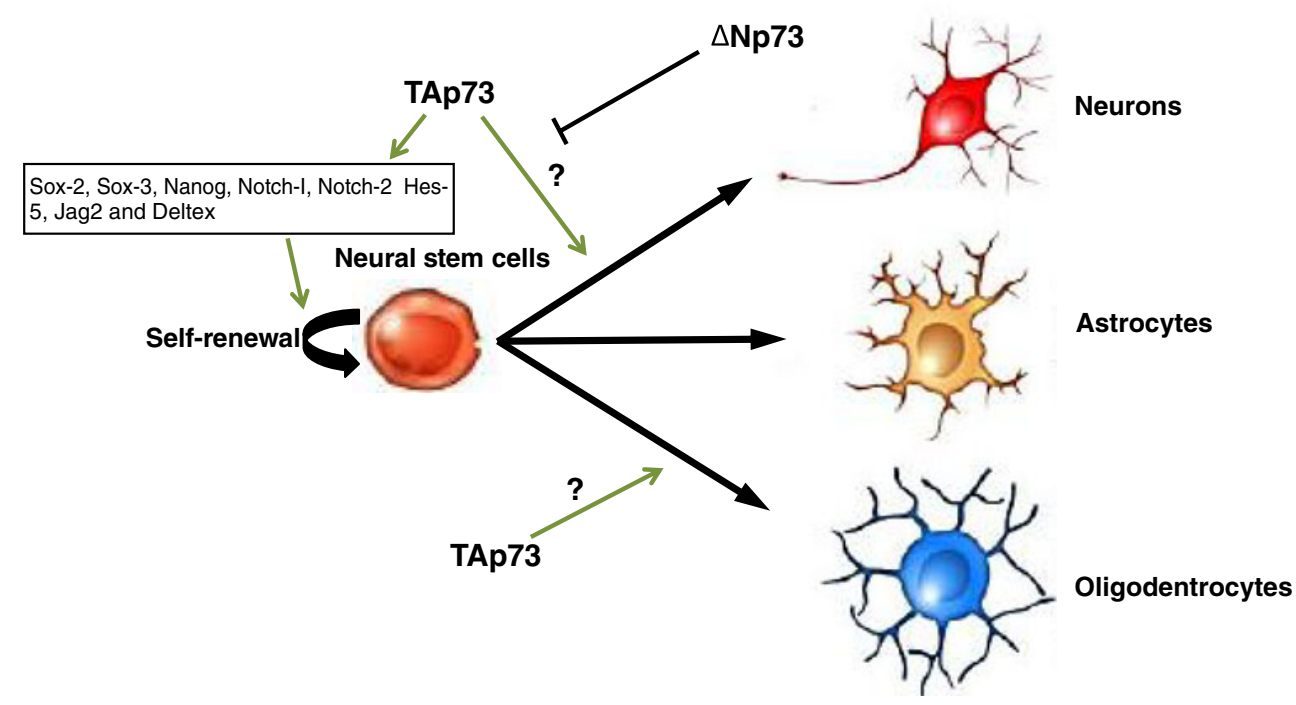


Open Access This article is distributed under the terms of the Creative Commons Attribution Noncommercial License which permits any noncommercial use, distribution, and reproduction in any medium, provided the original author(s) and source are credited.

\section{References}

1. Dötsch V, Bernassola F, Coutandin D, Candi E, Melino G (2010) p63 and p73 the ancestors of p53. Cold Spring Harb Perspect Biol 2:1-14

2. Melino G, De Laurenzi V, Vousden KH (2002) p73: friend or foe in tumorogenesis. Nat Rev Cancer 8:605-615

3. Vousden KH, Lane DP (2007) p53 in health and disease. Nat Rev Mol Cell Biol 8:275-283

4. Yang A, Kaghad M, Caput D, McKeon F (2002) On the shoulder of giants: p63, p73 and the rise of p53. Trends Genet 2:90-95

5. Muller M, Schilling T, Sayan AE, Kairat A, Lorenz K, SchulzeBergkamen H, Oren M, Koch A, Tannapfel A, Stremmel W, Melino G, Krammer PH (2005) TAp73/Delta Np73 influences apoptotic response, chemosensitivity and prognosis in hepatocellular carcinoma. Cell Death Differ 12:1564-1577

6. Wang J, Liu YX, Hande MP, Wong AC, Jin YJ, Yin Y (2007) TAp73 is a downstream target of p53 in controlling the cellular defense against stress. J Biol Chem 282:29152-29162

7. Grob TJ, Novak U, Maisse C, Barcaroli D, Lüthi AU, Pirnia F, Hügli B, Graber HU, De Laurenzi V, Fey MF, Melino G, Tobler A (2001) Human delta Np73 regulates a dominant negative feedback loop for TAp73 and p53. Cell Death Differ 8:1213-1223

8. De Laurenzi V, Costanzo A, Barcaroli D, Terrinoni A, Falco M, Annicchiarico-Petruzzelli M, Levrero M, Melino G (1998) Two new p73 splice variants, gamma and delta, with different transcriptional activity. J Exp Med 188:1763-1768

9. De Laurenzi VD, Catani MV, Terrinoni A, Corazzari M, Melino G, Costanzo A, Levrero M, Knight RA (1999) Additional complexity in p73: induction by mitogens in lymphoid cells and identification of two new splicing variants epsilon and zeta. Cell Death Differ 6:389-390

10. Murray-Zmijewski F, Lane DP, Bourdon JC (2006) p53/p63/p73 isoforms: an orchestra of isoforms to harmonise cell differentiation and response to stress. Cell Death Differ 13:962-972

11. Pozniak CD, Radinovic S, Yang A, McKeon F, Kaplan DR, Miller FD (2000) An antiapoptotic role for the p53 family member, p73, during developmental neuron death. Science 289:304-306

12. Kaghad M, Bonnet H, Yang A, Creancier L, Biscan JC, Valent A, Minty A, Chalon P, Lelias JM, Dumont X, Ferrara P, McKeon F, Caput D (1997) Monoallelically expressed gene related to p53 at $1 \mathrm{p} 36$, a region frequently deleted in neuroblastoma and other human cancers. Cell 90:809-819

13. Bagchi A, Mills AA (2008) The quest for the $1 \mathrm{p} 36$ tumor suppressor. Cancer Res 68:2551-2556

14. Campeau PM, Ah Mew N, Cartier L, Mackay KL, Shaffer LG, Der Kaloustian VM, Thomas MA (2008) Prenatal diagnosis of monosomy 1p36: a focus on brain abnormalities and a review of the literature. Am J Med Genet A 146A:3062-3069

15. Yang A, Walker N, Bronson R, Kaghad M, Oosterwegel M, Bonnin J, Vagner C, Bonnet H, Dikkes P, Sharpe A, McKeon F, Caput D (2000) p73-Deficient mice have neurological, pheromonal and inflammatory defects but lack spontaneous tumors. Nature 404:99-103

16. Talos F, Abraham A, Holembowski L, Vaseva AV, Tsirka S, Scheel A, Bode D, Dobbelstein M, Brück W, Moll UM (2010) p73 is an essential regulator of neural stem cell maintenance in embryonal and adult CNS neurogenesis. Cell Death Differ 17 (12):1816-1829
17. Pozniak CD, Barnabé-Heider F, Rymar VV, Lee AF, Sadikot AF, Miller FD (2002) p73 is required for survival and maintenance of CNS neurons. J Neurosci 22:9800-9809

18. Lee AF, Ho DK, Zanassi P, Walsh GS, Kaplan DR, Miller FD (2004) Evidence that DeltaNp73 promotes neuronal survival by p53-dependent and p53-independent mechanisms. J Neurosci 24:9174-9184

19. Wilhelm MT, Rufini A, Wetzel MK, Tsuchihara K, Inoue S, Tomasini R, Itie-Youten A, Wakeham A, Arsenian-Henriksson M, Melino G, Kaplan DR, Miller FD, Mak TW (2010) Isoformspecific p73 knockout mice reveal a novel role for delta $\mathrm{Np} 73$ in the DNA damage response pathway. Genes Dev 24:549-560

20. Yankner BA, Lu T, Loerch P (2008) The aging brain. Annu Rev Pathol 3:41-66

21. Tissir F, Ravni A, Achouri Y, Riethmacher D, Meyer G, Goffinet AM (2009) DeltaNp73 regulates neuronal survival in vivo. Proc Natl Acad Sci USA 106:16871-16876

22. Tomasini R, Tsuchihara K, Wilhelm M, Fujitani M, Rufini A, Cheung CC, Khan F, Itie-Youten A, Wakeham A, Tsao MS, Iovanna JL, Squire J, Jurisica I, Kaplan D, Melino G, Jurisicova A, Mak TW (2008) TAp73 knockout shows genomic instability with infertility and tumor suppressor functions. Genes Dev 22:2677-2691

23. Fujitani M, Cancino GI, Dugani CB, Weaver IC, GauthierFisher A, Paquin A, Mak TW, Wojtowicz MJ, Miller FD, Kaplan DR (2010) TAp73 acts via the bHLH Hey2 to promote long-term maintenance of neural precursors. Curr Biol 20 (22):2058-2065

24. Gage FH (2000) Mammalian neural stem cells. Science 287 (5457):1433-1438

25. Meletis K, Wirta V, Hede SM, Nistér M, Lundeberg J, Frisén J (2006) p53 suppresses the self-renewal of adult neural stem cells. Development 133:363-369

26. Dugani CB, Paquin A, Fujitani M, Kaplan DR, Miller FD (2009) p63 antagonizes p53 to promote the survival of embryonic neural precursor cells. J Neurosci 29:6710-6721

27. Agostini M, Tucci P, Chen H, Knight RA, Bano D, McKeon F, Nicotera P, Melino G (2010) p73 regulates maintenance of neural stem cell. Biochem Biophys Res Commun 403:13-17

28. González-Cano L, Herreros-Villanueva M, Fernández-Alonso R, Ayuso-Sacido Á, Meyer G, García-Verdugo JM, Silva A, Marqués MM, Marín MC (2010) p73 deficiency results in impaired selfrenewal and premature neuronal differentiation of mouse neural progenitors independently of p53. Cell Death Dis. doi:10.1038/ cddis. 2010.87

29. Molofsky AV, Pardal R, Morrison SJ (2004) Diverse mechanisms regulate stem cell self-renewal. Curr Opin Cell Biol 16:700-707

30. Billon N, Terrinoni A, Jolicoeur C, McCarthy A, Richardson WD, Melino G, Raff M (2004) Roles for p53 and p73 during oligodendrocyte development. Development 131:1211-1220

31. De Laurenzi V, Raschellá G, Barcaroli D, AnnicchiaricoPetruzzelli M, Ranalli M, Catani MV, Tanno B, Costanzo A, Levrero M, Melino G (2000) Induction of neuronal differentiation by $\mathrm{p} 73$ in a neuroblastoma cell line. J Biol Chem 275:15226-15231

32. Corasaniti MT, Melino G, Navarra M, Garaci E, Finazzi-Agrò A, Nisticò G (1995) Death of cultured human neuroblastoma cells induced by HIV-1 gp120 is prevented by NMDA receptor antagonists and inhibitors of nitric oxide and cyclooxygenase. Neurodegeneration 4(3):315-321

33. Ramadan S, Terrinoni A, Catani MV, Sayan AE, Knight RA, Mueller M, Krammer PH, Melino G, Candi E (2005) p73 induces apoptosis by different mechanisms. Biochem Biophys Res Commun 331:713-717

34. Burke JR, Roses AD (1991) Genetics of Alzheimer's disease. Int J Neurol 25-26:41-51 
35. Harold D et al (2009) Genome-wide association study identifies variants at CLU and PICALM associated with Alzheimer's disease. Nat Genet 41:1088-1093

36. Lambert JC et al (2009) Genome-wide association study identifies variants at CLU and CR1 associated with Alzheimer's disease. Nat Genet 41:1094-1099

37. De Strooper B (2010) Proteases and proteolysis in Alzheimer disease: a multifactorial view on the disease process. Physiol Rev 90:465-494

38. Hanger DP, Anderton BH, Noble W (2009) Tau phosphorylation: the therapeutic challenge for neurodegenerative disease. Trends Mol Med 15:112-119

39. Hardy J, Allsop D (1991) Amyloid deposition as the central event in the aetiology of Alzheimer's disease. Trends Pharmacol Sci $12: 383-388$

40. LaFerla FM, Hall CK, Ngo L, Jay G (1996) Extracellular deposition of beta-amyloid upon p53-dependent neuronal cell death in transgenic mice. J Clin Invest 98:1626-1632

41. Ferreira A, Kosik KS (1996) Accelerated neuronal differentiation induced by p53 suppression. J Cell Sci 109:1509-1516

42. Culmsee C, Zhu X, Yu QS, Chan SL, Camandola S, Guo Z, Greig NH, Mattson MP (2001) A synthetic inhibitor of p53 protects neurons against death induced by ischemic and excitotoxic insults, and amyloid beta-peptide. J Neurochem 77:220-228

43. Kitamura Y, Shimohama S, Kamoshima W, Matsuoka Y, Nomura Y, Taniguchi T (1997) Changes of p53 in the brains of patients with Alzheimer's disease. Biochem Biophys Res Commun 232:418-421

44. Hooper C, Meimaridou E, Tavassoli M, Melino G, Lovestone S, Killick R (2007) p53 is upregulated in Alzheimer's disease and induces tau phosphorylation in HEK293a cells. Neurosci Lett 418:34-37

45. Caricasole A, Copani A, Caraci F, Aronica E, Rozemuller AJ, Caruso A, Storto M, Gaviraghi G, Terstappen GC, Nicoletti F (2004) Induction of Dickkopf-1, a negative modulator of the Wnt pathway, is associated with neuronal degeneration in Alzheimer's brain. J Neurosci 24:6021-6027

46. Wang J, Shou J, Chen X (2000) Dickkopf-1, an inhibitor of the Wnt signaling pathway, is induced by $\mathrm{p} 53$. Oncogene 19:1843-1848

47. Wilson C, Henry S, Smith MA, Bowser R (2004) The p53 homologue p73 accumulates in the nucleus and localizes to neurites and neurofibrillary tangles in Alzheimer disease brain. Neuropathol Appl Neurobiol 30:19-29

48. Hooper C, Killick R, Tavassoli M, Melino G, Lovestone S (2006) TAp73alpha induces tau phosphorylation in HEK293a cells via a transcription-dependent mechanism. Neurosci Lett 401:30-34

49. Wetzel MK, Naska S, Laliberté CL, Rymar VV, Fujitani M, Biernaskie JA, Cole CJ, Lerch JP, Spring S, Wang SH, Frankland
PW, Henkelman RM, Josselyn SA, Sadikot AF, Miller FD, Kaplan DR (2008) p73 regulates neurodegeneration and phospho-tau accumulation during aging and Alzheimer's disease. Neuron 59:708-721

50. Walsh GS, Orike N, Kaplan DR, Miller FD (2004) The invulnerability of adult neurons: a critical role for $\mathrm{p} 73$. J Neurosci 24:9638-9647

51. Okazawa H, Estus S (2002) The JNK/c-Jun cascade and Alzheimer's disease. Am J Alzheimers Dis Other Demen 17:79-88

52. Shoji M, Iwakami N, Takeuchi S, Waragai M, Suzuki M, Kanazawa I, Lippa CF, Ono S, Okazawa H (2000) JNK activation is associated with intracellular beta-amyloid accumulation. Brain Res Mol Brain Res 85:221-233

53. Sahara N, Murayama M, Lee B, Park JM, Lagalwar S, Binder LI, Takashima A (2008) Active c-jun N-terminal kinase induces caspase cleavage of tau and additional phosphorylation by GSK3 beta is required for tau aggregation. Eur J Neurosci 27:28972906

54. Reynolds $\mathrm{CH}$, Utton MA, Gibb GM, Yates A, Anderton BH (1997) Stress-activated protein kinase/c-jun N-terminal kinase phosphorylates tau protein. J Neurochem 68:1736-1744

55. Mudher A, Chapman S, Richardson J, Asuni A, Gibb G, Pollard C, Killick R, Iqbal T, Raymond L, Varndell I, Sheppard P, Makoff A, Gower E, Soden PE, Lewis P, Murphy M, Golde TE, Rupniak HT, Anderton BH, Lovestone S (2001) Dishevelled regulates the metabolism of amyloid precursor protein via protein kinase $\mathrm{C} /$ mitogen-activated protein kinase and c-Jun terminal kinase. $\mathrm{J}$ Neurosci 21:4987-4995

56. Braithwaite SP, Schmid RS, He DN, Sung ML, Cho S, Resnick L, Monaghan MM, Hirst WD, Essrich C, Reinhart PH, Lo DC (2010) Inhibition of c-Jun kinase provides neuroprotection in a model of Alzheimer's disease. Neurobiol Dis 39:311-317

57. Liou YC, Sun A, Ryo A, Zhou XZ, Yu ZX, Huang HK, Uchida T, Bronson R, Bing G, Li X, Hunter T, Lu KP (2003) Role of the prolyl isomerase Pin1 in protecting against age-dependent neurodegeneration. Nature 424:556-561

58. Mantovani F, Piazza S, Gostissa M, Strano S, Zacchi P, Mantovani R, Blandino G, Del Sal G (2004) Pin1 links the activities of c-Abl and p300 in regulating p73 function. Mol Cell 14:625-636

59. Alvarez AR, Sandoval PC, Leal NR, Castro PU, Kosik KS (2004) Activation of the neuronal c-Abl tyrosine kinase by amyloid-betapeptide and reactive oxygen species. Neurobiol Dis 17:326-336

60. Vazquez MC, Vargas LM, Inestrosa NC, Alvarez AR (2009) c-Abl modulates AICD dependent cellular responses: transcriptional induction and apoptosis. J Cell Physiol 220:136-143

61. Checler F, Dunys J, Pardossi-Piquard R, Alves da Costa C (2010) p53 is regulated by and regulates members of the gammasecretase complex. Neuro-degenerative Dis 7:50-55 